\title{
KAFKA E O ELEMENTO MÍTICO DA LEI MODERNA: UM ESTUDO A PARTIR DA LEITURA DE PETER FITZPATRICK
}

\author{
Ricardo ARAujo Dib TAXI ${ }^{1}$
}

\begin{abstract}
RESUMO: O artigo busca apresentar a leitura de Kafka desenvolvida pelo filósofo australiano Peter Fitpzatrick, inserindo-a no contexto de sua reflexão crítica aos fundamentos míticos da lei moderna. Apresentando brevemente pontos centrais da teoria de Fitzpatrick, o artigo busca abordar o potencial de novelas e contos kafkianos na desconstrução de alguns dos paradigmas que animam a concepção moderna de lei. Mais ainda, buscar-se-á mostrar que a desconstrução dos elementos míticos da lei tem um papel emancipatório, qual seja o de trazer à tona os elementos de racismo, imperialismo, colonialismo e violência que se escondem sob o discurso tradicional de um direito racional.
\end{abstract}

Palavras-Chave: Kafka; Fitzpatrick; mitologia; teoria crítica; lei moderna.

\begin{abstract}
"É nesse fio da navalha que nós vivemos. Certa vez um escritor resumiu isso da seguinte maneira: a única lei visível e indubitavelmente imposta a nós é a nobreza - e será que queremos espontaneamente nos privar dela?” (Kafka, 2002, p. 125).
\end{abstract}

\section{INTRODUÇÃO}

O presente artigo tem como objetivo discutir a leitura da obra de Franz Kafka apresentada pelo filósofo australiano Peter Fitzpatrick (2015)

\footnotetext{
Graduado em Direito Pelo Centro Universitário do Pará (CESUPA). Mestre em direitos humanos pela Universidade Federal do Pará (UFPA) com período sanduíche na Universidade do Vale do Rio dos Sinos (UNISINOS), sob supervisão do Prof. Alfredo Santiago Culleton. Doutor em Direitos Humanos pela Universidade Federal do Pará (UFPA), com período sanduiche na Birkbeck College (University of London), sob coorientação do Prof. Peter Fitpzatrick. Professor adjunto de Direito Civil da Universidade Federal do Pará (UFPA). Professor de Introdução ao Estudo do Direito e Filosofia do Direito do Centro Universitário do Pará (CESUPA). Belém (PA). CV Lattes: http://lattes.cnpq.br/2208519070757294. ORCID: https://orcid.org/O000-0002-49506112. E-mail: ricardoadt@gmai.com.
} 
enquanto parte de uma leitura crítica acerca dos fundamentos do direito moderno. Ao contrário de chaves hermenêuticas, que privilegiam as noções de burocracia e os exageros racionalistas da modernidade, a leitura aqui oferecida buscará resgatar os elementos míticos presentes na lei moderna.

Para introduzir a leitura de Fitzpatrick, em todo caso, faz-se necessário primeiramente contextualizar a recepção da obra kafkiana. Sendo um autor de leitura bastante densa, que trouxe desde elementos da teologia judaica até componentes jurídicos e sociológicos, e sua obra objeto de distintas interpretações ao longo do século XX, mostra-se relevante precisar ao menos alguma delas, de modo a contextualizar a tradição a partir da qual a crítica do filósofo australiano se insere.

Além disso, o artigo aborda também a obra de Fitzpatrick face ao pensamento jurídico crítico contemporâneo, apontando algumas de suas principais influências como o pós-estruturalismo e a desconstrução, buscando construir um argumento teórico no qual a literatura não seja apenas um exemplo ou um auxílio à reflexão filosófica, mas tenha o papel fundamental de questionar o tipo de certeza e de racionalidade no qual se fundam as noções modernas de verdade e ciência.

Por fim, a partir dos elementos teóricos trazidos, a presente pesquisa procura evidenciar como a literatura kafkiana pode, a partir da interpretação aqui defendida, exercer um papel importante de resistência crítica, na medida em que permite desvelar os elementos de violência, arbitrariedade e contradição que permeiam a experiência moderna e contemporânea do direito.

A metodologia da pesquisa se dará basicamente a partir do confronto entre textos do escritor tcheco e comentários críticos de pensadoras e pensadores cujas obras de alguma forma se confrontaram com Kafka. Nesse sentido, não se buscará defender a presente leitura como a mais fiel ou como aquela que resgata a intenção do autor, mas se mostrará a todo momento como elementos fundamentais foram inseridos e construídos por meio da tradição de leitura do autor, por questões que foram surgindo e cujo confronto exigiu o retorno a Kafka. Trata-se, assim, de uma confrontação do horizonte das questões propostas a partir da obra kafkiana com elementos fundamentais que, se não foram originalmente pensados pelo escritor, parecem inexoravelmente levar ao seu encontro. 


\section{A POSIÇÃO DA LEITURA DE FITZPATRICK NA TRADIÇÃO DE INTERPRETAÇÕES DE KAFKA}

O pesadelo de ruas que não levam a lugar nenhum, da lei cujas entradas estão vedadas, dos castelos inalcançáveis e do diálogo impossível é tão drástico e aparentemente absoluto que sua influência deu origem ao adjetivo "kafkiano" (em inglês Kafkaesque), que denota usualmente uma situação confusa e aterrorizante, geralmente envolvendo sistemas ou regras que parecem não fazer qualquer sentido.

O lugar onde o terror surrealista desse labirinto parece incidir com mais força é justamente a corte de direito, o chamado palácio da justiça, talvez por ser o lugar em que tradicionalmente o equilíbrio quebrado em dada relação é restaurado. Em uma leitura mais próxima da modernidade, o tribunal é o local da aplicação racional de uma lei fria e impessoal. Nada disso pode ser mais distante do universo kafkiano, no qual o acesso à lei se encontra atrás de portas intransponíveis, guardada, operada e julgada por pessoas cuja mediocridade só torna ainda mais resplandecente a inevitabilidade e a brutalidade da violência (Gewalt) inerente ao direito.

Na leitura de Max Brod (Brod, 1987), biógrafo e um dos primeiros a realizar uma exegese abrangente do escritor tcheco, toda a obscuridade e a ausência de sentido no mundo das novelas de Kafka é lida como um caminho para uma espécie de "evolução religiosa", busca por reconhecimento da graça de Deus, mas de um Deus que enviou mensagens que se perderam e agora precisam ser reencontradas, tal qual a mensagem imperial. A esperança então, se é que existe esperança para um personagem como K., se situa num caminho que conduz ao sionismo e à busca de uma transcendência que fora perdida e precisa ser reencontrada (Santos, 2017).

Curiosamente, quando pensada com relação ao direito, tal leitura dialoga tanto com a busca de uma transcendência religiosa de estilo jusnaturalista, pela reabilitação das condições ontológicas para que um raciocínio ético possa ressurgir ${ }^{2}$, quanto com a promessa de certo marxismo que vê a redenção no fim da história, no desfecho dialético. De fato, sendo Max Brod judeu sionista e o melhor amigo de Kafka, também judeu, a amizade muitas vezes levou Brod a ver no desespero do amigo um mal cujo

O grande desafio filosófico da hermenêutica jurídica contemporânea tem sido justamente reabilitar um raciocínio prudencial e moral sem resgatar uma ontologia essencialista. 
remédio se encontrava em uma maior aproximação à religião judaica, com a qual o romancista não tivera uma relação próxima durante toda sua vida.

Contrariamente a essa leitura, o filósofo do direito australiano Peter Fitzpatrick retoma com a leitura de Walter Benjamin os elementos teológicos de Kafka para levar a um caminho contrário ao delineado por Max Brod (Benjamin, 1987). Em um ensaio de 1934, comemorativo aos 10 anos da morte de Kafka, Benjamin já havia criticado a lógica do pensamento de Brod, embora mantendo a aproximação teológica. Como afirma Bruno Santos,

o jogo das categorias teológicas presentes na leitura brodiana é estrategicamente invertido por Benjamin ao estabelecer dois eixos centrais para a interpretação da obra Kafkiana, sendo: a experiência mística e a vida do homem da grande cidade (Santos, 2017, p. 2).

É justamente a busca de uma espécie de elemento místico ou teológico nessa experiência da burocracia racional moderna o que de certa forma se encontra com a tese de Fitzpatrick, na medida em que permite desvelar o direito moderno não pelas narrativas vistas como paradigmáticas, mas a partir dos pontos excluídos 3 , daquilo que é ali negado. Esse elemento teológico, contudo, não é posto como a tentativa ou a esperança de um resgate dos fios rompidos de uma ligação com um sentido transcendente ou tradicionalmente forjado, mas justamente como a percepção de que determinabilidade e indeterminabilidade mantêm uma estranha relação estrutural, dentro da qual se move, como que num fio de navalha, a linguagem do pensamento crítico do autor.

Em Benjamin, a experiência mística perdeu sua verdade e as parábolas se tornaram intransmissíveis, estando agora em ruínas, refletidas também no aparato burocrático da modernidade. Nesse mundo, como já dito, o direito é inacessível, invasivo, totalizante, porém ausente. Em suma, mostra-se incapaz de cumprir ou mesmo de tornar cognoscíveis os seus desígnios.

\footnotetext{
Essa perspectiva é o que permite inserir a leitura de Fitzpatrick no âmbito de uma discussão pós-estruturalista, na medida em que busca discutir o objeto não a partir dos elementos que lhe são centrais, mas daqueles que são periféricos, que estão excluídos ou relegados às bordas. Se é possível pensar o direito moderno como tendo um núcleo (core) racional e baseado na rule of law e extremidades (borderline) irracionais ou relegadas ao arbítrio de autoridades, em Fitzpatrick as noções de núcleo e extremidades são solapadas, uma vez que o elemento por excelência que o direito moderno buscou excluir, que é uma justificativa transcendente ao fenômeno jurídico, é trazido de volta como aquilo que anima o movimento narrativo das grandes teorias do direito como as de Hart e Dworkin, dentre outros.
} 
Fitzpatrick ressalta essa aporia quando destaca que

Em $O$ Processo essa estrutura aporética é evocada em sua ausência e na busca impelida por uma lei sempre inalcançável. No entanto, o julgamento, o processo, continua interminável. $\mathrm{O}$ direito permanece indistinto em toda parte. E isso é variável e fugaz. Então, no final do romance, a parábola "Antes da Lei" fornece um corretivo, instaurando a oposição duradoura entre o direito determinado, que é limitado, e o direito ilimitado (Fitzpatrick, 2015, p. 113).

O fato de o elemento teológico estar presente tanto em Brod quanto em Benjamin não conduz à conclusão de que ambos apontam para a busca de uma transcendência perdida. Nesse ponto, deve-se a Jeane Marie Gagnebin a precisa distinção entre teologia e religião, a qual é importante assinalar desde já na medida em que a leitura de Benjamin - o que vale também para a de Fitzpatrick - é teológica, porém jamais religiosa.

Para o primeiro aclaramento do que significa aqui o elemento teológico, pode-se lembrar, com Gagnebin, que se trata de apontar para uma incompletude ou busca que chega sempre tarde e que é teológica exatamente na medida em que está lidando com o insondável, com aquilo que precisa necessariamente ser pensado, mas que ao mesmo tempo escapa de nossa capacidade e mesmo parece transcender os limites do que a linguagem pode nomear (Gagnebin, 2014, p. 194).

Se, em todo caso, o direito se encontra nesse "não lugar", nessa intransmissibilidade de sentido, sua posição nos autores aqui analisados não é a mesma.

Fitzpatrick ressalta mais uma vez elementos na obra de Kafka que apontam para essa estrutura aporética quando lembra que no Processo

o trabalho de formação negativa começa com o título. Não há processo. Ou o título poderia ser traduzido como o julgamento. Não há julgamento. E de certo modo o romance não poderia chegar a isso por ser reputado inacabado. No entanto, a incompletude é adequada, uma vez que o romance persegue insistentemente a irresolução. E a figura central dessa irresolução e da lei onde toda a realidade é a lei, é o tribunal (Fitzpatrick, 2015, p. 102).

Em todo caso, a interpretação kafkiana desenvolvida por Peter Fitzpatrick em uma série de artigos apresenta outra possibilidade de leitura, na qual a obra de Kafka possibilita uma leitura crítica que, ao invés de ressaltar as passagens inacessíveis e os labirintos intermináveis, evidencia a 
potencialidade crítica no sentido positivo, como agir que rompe com as tentativas de acesso, que de outro modo apareceriam sempre como inacessíveis.

O resgate dessa possibilidade crítica em um sentido não apenas negativo, mas apontando para uma espécie de possibilidade de redenção do direito, a ser aqui explorada com Fitzpatrick, parte de uma rota de exploração do universo Kafkiano que já fora aberta por Benjamin, embora em sua leitura o direito seja quase sempre exposto apenas como algo negativo e sem qualquer possibilidade emancipatória com relação ao labirinto kafkiano.

A abertura desse caminho necessita, em todo caso, que se perceba o elemento mítico que o direito tem não apenas na narrativa kafkiana, mas em suas mais básicas formulações modernas.

\section{O MITO NA LEI MODERNA}

A Mitologia na lei moderna, de Peter Fitzpatrick, é uma obra de clara influência foucaultiana e derridiana, verificável na medida em que seu autor, no dizer dos escritores de seu prefácio,

Desconstrói o mito ocidental que funda e permeia a lei. Mito é uma forma que unifica (aparentemente) sem totalizar, uma forma que mantém a unidade na aparente inconsistência e a presença na aparente ausência. Este livro, portanto, revela que a mitologia não existe só em "outras" sociedades, mas impregna a nossa própria, e talvez seja até mais forte naqueles lugares em que sua ausência é proclamada mais ruidosamente, ou seja, naqueles locais em que se conjugam a razão e a sisudez, a saber: na lei e nas ciências (Cain; Smart, 2005, p. 20).

Identificar o direito moderno e a ciência moderna como reinos míticos é um passo bastante radical, na medida em que contraria o próprio elemento fundamental do mito da modernidade, que é a superação de qualquer transcendência, de qualquer explicação mítica ou religiosa. Tudo isso faria parte de um passado quase pré-histórico. $\mathrm{O}$ ato de identificar a persistência do mito na modernidade precisa, nesse sentido, desconstruir as narrativas de autoidentificação da modernidade.

A obra não busca, por outro lado, substituir uma visão moderna por outra visão que, ao incorporar o mito, apresente o direito com a mesma pretensão de clareza com que a modernidade o apresenta, substituindo apenas uma imagem pela outra. Ao contrário, a imagem do direito que 
exsurge da obra de Fitzpatrick é borrada, difícil de enxergar, uma dificuldade que se torna inclusive linguística e torna a leitura do livro bastante difícil.

A partir de uma abordagem pós-estruturalista, busca iluminar não o que o direito "verdadeiramente é", mas mostrar que essa suposta identidade escapa de nossas mãos quando tentamos apreendê-la. A compreensão disso perpassa a noção de que o direito moderno se constitui fundamentalmente de uma série de narrativas aporéticas que só adquirem sentido unitário e racional a partir de uma narrativa mais abrangente de ordem mítica.

Se no estruturalismo, que foi uma das correntes dominantes na filosofia francesa da segunda metade do século XX, o conhecimento era concebido a partir de estruturas definidas, dentro das quais as singularidades e a ação individual eram reduzidas em prol de uma visão que só compreendia as particularidades e criações como um jogo interno e subsumido no arquétipo geral, o pós-estruturalismo respeita a singularidade justamente na medida em que privilegia aquilo que é negado pela estrutura, aquilo que está no seu limite.

Para trazer um argumento central ao pós-estruturalismo, pode-se dizer que o que define algo não é o seu âmago, mas suas bordas, os seus limites (Williams, 2005). Assim, se a lei moderna se define pela burocratização, racionalidade, os elementos irracionais, míticos e arbitrários só podem aparecer ou como elementos negados ou como exceções que se situam às margens da caracterização geral da modernidade jurídica. O pós-estruturalismo, na tese de Fitzpatrick, é visto precisamente na tentativa de mostrar que esses elementos marginais estão na verdade no âmago da modernidade, como a sua face oculta, como o elemento escondido que abalaria a coerência da construção.

Em outras palavras, ao invés de trilhar um caminho mais óbvio e mostrar que o direito moderno afirma ser "A" quando na verdade é "B", Fitzpatrick dirá que a noção moderna de lei, como qualquer narrativa mítica ocidental, escapa de uma apreensão seja em termos fáticos seja em termos de um conjunto de convenções que podem simplesmente ser apontadas e corporificadas. 
Para antecipar algo da hipótese, a leitura do direito moderno como uma narrativa mítica não implica que a prática social do direito seja uma ilusão ${ }^{4}$, que suas bases são puras invenções que se dissolvem quando um olhar mais crítico se aproxima. O ponto na verdade é mostrar que existe uma tensão entre determinação e indeterminação e que é justamente essa tensão, essa ausência, que permite que arbitrariedade, racismo, machismo, xenofobia, privilégios etc. convivam perfeitamente com os aspectos de universalidade, igualdade, segurança que são tidos como baluartes do direito moderno.

Claro que, em sua arrogância, a lei moderna jamais poderia admitir elementos mitológicos em sua construção. Sua narrativa se deu justamente tendo como elemento central o fato de haver expulsado elementos míticos, religiosos e transcendentes de sua explicação da lei (Fitzpatrick, 2005). O reino do sagrado tornou-se parte daquele direito retrógrado que nós modernos deixamos para trás. A teoria de Fitzpatrick é crítica, portanto, na medida em que traz à tona essa persistência incômoda do mito na narrativa do direito moderno e abre o caminho para a percepção da violência que esse velamento possibilita.

Existe aqui uma perspectiva descolonial que só fica clara quando se vê com atenção a forma como Fitzpatrick reconstrói a narrativa da lei moderna. Identificando narrativas míticas com aquilo que é estático e invariável, a modernidade seria sinônimo de mudança enquanto progresso. Em sua empreitada universalizante, o elemento moderno precisa se expandir. É nessa expansão que a modernidade cria os monstros que necessita enfrentar: selvagens, pessoas que vivem em condições atrasadas e que precisam ser trazidas à luz do progresso. É em negação a essas pessoas que a modernidade é finalmente identificada com um conteúdo palpável. Moderno é o oposto desses monstros e selvagens que precisam ser domesticados, catequizados etc.

\footnotetext{
A afirmação de que o direito, no sentido de seus códigos de normas, códigos de conduta das autoridades, princípios orientadores, legitimidade etc. é uma construção social forjada por uma série de práticas constituídas por convenções, leitura essa sustentada pelos principais teóricos do direito da chamada jurisprudência analítica, torna por si só mal colocada a questão acerca do direito ser uma "ilusão" ou possuir uma existência de fato. Quando afirmei acima que para Fitzpatrick o elemento mítico do direito não implica que a prática jurídica seja mera ilusão, me referi justamente às convenções e à previsibilidade supostamente advindas do conhecimento das práticas e seu sentido.
} 
Em artigo intitulado "Political Agonism and the (Im)possibility of Law: Kafka's Solution”, a relação entre essa leitura da constituição moderna da lei como uma denominação negativa e a literatura kafkiana fica evidente quando se lê que "Parece impossível que a lei tenha algum conteúdo positivo, qualquer conteúdo que exista em si mesmo. Ao invés da busca por conteúdo em termos positivos, talvez uma busca por conceituação negativa possa ser mais promissora, e é aí que Kafka entra" (Fitzpatrick, 2015, p. 101).

A menção a Kafka remete justamente à estrutura aporética da inacessibilidade da lei, de uma presença que se dá por meio de uma totalidade e de um vazio. Ao contrário de uma leitura negativa, na qual o personagem fracassa por buscar o inacessível, Fitzpatrick lê o fracasso de K. como um fracasso positivo, que poderia ser resumido como a percepção do elemento de indeterminabilidade que é constitutivo do experienciar da lei.

Há dois trechos de Kafka que Fitzpatrick já, por mais de uma vez, usou para ilustrar esse argumento. A primeira e mais conhecida é a da lei (Gesetz) que se encontra de portas abertas, mas cuja entrada está vedada ao camponês, ilustrada no famoso "Diante da Lei" que consta no nono capítulo de $O$ processo e que também foi publicado de forma separada nas coletâneas de pequenos textos kafkianos. A segunda metáfora, constante do pequeno texto "Sobre a questão das leis", publicado em Narrativas do espólio (Kafka, 2002, p. 123) conta a estória de uma lei que se acredita que exista, mas que apenas os nobres conhecem. O resto da população precisa observar o comportamento dos nobres para saber o conteúdo da lei, para saber o que lhes é proibido e permitido. Curioso é que, por mais que a existência da lei possa ser uma invenção (o povo não tem como saber se a lei existe de fato ou não) e que não haja nada além de arbítrio e dominação, o povo prefere tal lei do que nenhuma, pois a nobreza como uma lei em si ainda lhes parece melhor do que lei nenhuma (Kafka, 2012, p. 125).

Como se pode observar, ambos os relatos lidam com uma lei ausente ou inacessível e ainda assim de alguma forma presente. Não é com o nada que os relatos dialogam, no entanto.

Em ambas, embora abordem pontos distintos, há uma vedação, um caminho obstruído, mas ao mesmo tempo uma abertura, uma esperança de entrada ou de compreensão. 
Ambas colaboram na construção e no desenvolvimento daquilo que Fitzpatrick chama de mitologia da lei moderna.

\section{O LUGAR DE KAFKA NA RELAÇÃO ENTRE FILOSOFIA E LITERATURA}

Quando se lê os momentos estratégicos nos quais Kafka surge na argumentação teórica de Fitzpatrick, é de se pensar que seu interesse no prosador tcheco é bem mais central do que geralmente costuma se legar a uma obra literária no interior de uma argumentação filosófica.

Se Jeanne Marie está certa em sua argumentação exposta no artigo "Filosofia e literatura", de fato uma influente tradição que remete a Platão tornou-se quase hegemônica a esse respeito, de modo que, quando muito, a obra literária (enquanto criação artística) ocupa um posto secundário em relação à argumentação filosófica (Gagnebin, 2016). É importante mostrar aqui em que medida isso não acontece na obra de Fitzpatrick e o quanto isso pode ser instrutivo em termos da relação direito e literatura.

É usual que aproximações entre pensamento filosófico (incluindo jusfilosófico) e literatura se valham desta como um exemplo privilegiado de algo desvelado por aquele. Essa via foi aquela trilhada de maneira muito frutífera pelo filósofo paraense Benedito Nunes, que interpretou obras densas e muitas vezes difíceis, como os textos de Clarice Lispector e Guimarães Rosa, imputando a tais obras uma compreensibilidade forjada a partir de hipóteses filosóficas, as quais desvelam o potencial ontológico por trás daquelas obras de arte. Em outras palavras, é como se o romancista escrevesse de forma nebulosa, onírica, vindo então o filósofo a realizar o posterior aclaramento conceitual.

Jeanne Marie Gagnebin critica essa forma de aproximar os temas. Embora reconhecendo os méritos filosóficos que tem uma leitura heideggeriana ou sartreana de Lispector de Guimarães Rosa, Gagnebin questiona a posição privilegiada do filósofo e seu artifício conceitual, que remete ao modelo da leitura idealista de Platão (Gagnebin, 2012).

Se opondo a essa forma de enxergar a relação, em Gagnebin não é a filosofia quem dá forma e conceitos aos arroubos geniais da literatura, mas a literatura quem convida a uma reflexão sobre as formas literárias da filosofia. Não é a filosofia quem apaga a névoa do gênio artístico e permite o 
desvelamento da verdade, mas a literatura que permite que se questione a lógica entificada da verdade filosófica.

Trata-se precisamente através dessa terceira visão que este artigo pretende enxergar a relação entre Kafka e Fitzpatrick. Kafka não é um bom exemplo ou uma metáfora artística que só fica clara sob a luz da desconstrução e do pós-estruturalismo de Fitzpatrick, mas o movimento aporético de sua escrita constitui um elemento fundamental na própria construção teórica do filósofo australiano, na medida em que a leitura de um elemento mitológico inscrito na lei moderna só pode ser adequadamente compreendida a partir de uma narrativa que incorpore aporias para dentro de si como elementos constitutivos.

Jamais seria possível compreender Kafka ou Fitzpatrick de maneira assertiva, analítica, retirando algumas teses centrais e expondo-as de maneira lógica. Ao contrário, são raciocínios que só fazem sentido à medida que suas lógicas são inseridas em uma estrutura narrativa.

O ponto fulcral, no entanto, aparece quando se observa que essa narrativa aporética não é uma questão de estilo, mas imposta pela própria estrutura daquilo de que se fala. Fitzpatrick não é um autor que escreva toda sua obra de maneira intencionalmente difícil e por assim dizer parabólica, mas o fato de abordar a mitologia na lei moderna sob uma estrutura desconstrutiva mostra-se fundamental, na medida em que diz respeito à negação da narrativa corrente do direito moderno, visto como, é claro, cientificamente cognoscível ${ }_{5}$ etc.

Alberto Pucheu lembra em Kafka poeta como toda obra do escritor judeu fora trespassada pela tensão, pela luta entre ter que escrever sobre o indizível, entre trazer à tona caminhos que estão vedados. Pucheu cita um texto de Danielle Cohen intitulado "A escritura é um combate contra os deuses", onde se lê que "seu combate [o de Kafka] contra os deuses de Ulisses e o Deus de Abraão havia de alguma forma migrado para o outro lado da escrita, de uma vez por todas, sem esperança de encontrar uma phoné consoladora, o signo precisamente de nossa adesão ao mundo onde

5 Nada mostra mais a importância dessa escrita do que uma rápida leitura em artigos contemporâneos de jurisprudência analítica, os quais partem de certas teses vistas como conceitualmente necessárias e se escreve por meio de uma série de assertivas que congelam e artificializam os conceitos. 
ele nunca tinha se sentido completamente em casa” (Cohen apud Pucheu, 2015, p. 155).

Também na Carta ao pai essa tensão chega ao apogeu, como ilustra o seguinte trecho:

\begin{abstract}
A impossibilidade do intercâmbio tranquilo teve uma outra consequência, muito natural no fundo: eu desaprendi a falar. Por certo eu não teria sido, sendo outro o contexto, um grande orador, mas sem dúvida teria dominado a linguagem humana corrente e comum. No entanto, logo cedo você me interditou a palavra (Kafka, 1997a, p. 21).
\end{abstract}

Se perde muito quando se reduz esses relatos autobiográficos a uma tentativa de hermenêutica psicológica, no sentido de que tais relatos são importantes para entender o espírito do autor como uma individualidade inventiva. Deleuze e Guatarri (2014) lembram que Kafka, sendo tcheco e escrevendo em alemão, sempre foi um estrangeiro em sua própria "língua oficial”, assim como sua criação judaica o tornava estrangeiro em sua cidade. Contudo, o equívoco hermenêutico seria reduzir a experiência desse estranhamento (Fremdheit) a uma idiossincrasia daquela pessoa, e não a entender como a experiência de uma época, ou ao extremo da experiência da falência das promessas do direito moderno e do pensamento moderno de um modo geral.

Voltando à questão da teoria crítica do direito em Fitzpatrick, a experiência da literatura kafkiana possui um potencial fundamental exatamente na medida em que desvela o caráter de estranhos, estrangeiros (Fremd) em que nos encontramos diante da lei. Para tanto, uma pequena reflexão filosófica acerca dos termos presentes no título da parábola kafkiana é importante.

O título original da parábola é "Vor dem Gesetz" (Kafka, 2008). O termo Vor, traduzido no português como "diante", possui no alemão dois sentidos, remetendo tanto ao que está frente a frente com algo como ao que vem antes de algo. A tradução inglesa "Before the Law" é mais fiel a esse duplo sentido do alemão, pois evoca tanto o ato de se prostrar sob o jugo da lei quanto a questão de que a parábola diz respeito a algo anterior, prefacial à lei.

Mais instrutiva ainda é a escolha de Kafka do termo Gesetz ao invés de Recht. Não se trata do direito como um todo, mas da lei, daquilo que 
enquadra, que constrói e permite que algo seja visto como sendo algo. Hans Kelsen mostrou essa questão de modo fundamental no primeiro capítulo de sua Teoria pura do direito quando salientou que a norma funciona como esquema de interpretação, isto é, que a norma atribui a determinadas situações, atos, fatos etc. um sentido conforme o direito (Kelsen, 1998).

Antes de proibir, permitir, obrigar, a lei constitui a relação segundo o direito. Se, portanto, o camponês não consegue entrar na lei (Gesetz), isso não significa simplesmente que não tem seu direito respeitado, mas que não tem a possibilidade de conhecer o que as suas relações significam de acordo com o direito, ou seja, que está no escuro a respeito do significado de suas ações.

Agora, se pensarmos que na modernidade a racionalidade estatal se dá fundamentalmente a partir do direito como códigos de leis e relações burocráticas legalmente constituídas, ser um estrangeiro na lei significa ser um estrangeiro no mundo, o que é justamente a tônica dos protagonistas das novelas e contos kafkianos.

François Ost percebeu que essa experiência de não-pertencimento foi sendo aguçada ao longo da obra kafkiana, como se o caminho da escrita do autor fosse o da percepção de um distanciamento cada vez maior entre o protagonista e o solo de sentido comum ao qual ele tenta pertencer. Se nos primeiros romances o nome do protagonista ainda era Gregor Samsa (Metamorfose), Karl Rossman (Amerika), em O processo o sobrenome já é perdido, tornando-se apenas Joseph K., culminando, no Castelo, com a perda também do nome, vindo a personagem principal a ser apenas K (Ost, 2004).

Esse sentimento de solidão e de perda da própria identidade em Kafka precisa ser enriquecido aqui com a percepção hegeliana de Judith Butler (2015), em Relatar a si mesmo - crítica da violência ética, a respeito da construção social do $e u$ e da dialética do reconhecimento, na qual nos reconhecemos como sujeitos em contraste com o outro e com um quadro prévio de sentido. Assim, a perda progressiva da identidade de K. é resultado também do apagamento e da torção contínua desse quadro de referência. Também o outro como tal não tem como ser bem percebido por K. 
Em seu já mencionado texto de 1934, Walter Benjamin (1987) percebeu que o mundo de Kafka, embora suas leis não sejam conhecidas e suas autoridades sejam inacessíveis, é um mundo da lei no sentido de que é uma espécie de mundo onde o protagonista anda com medo, sendo a todo tempo recriminado e punido por violar uma lei cujo conteúdo lhe é inacessível. A imagem aqui se assemelha a de um filho que em tudo desagrada ao pai, que não sabe o que pode ou não fazer, mas que desde o começo é culpado e vive com remorso. Benjamin diz que em Kafka o mundo das autoridades e o mundo dos pais parecem o mesmo.

Mais ainda, Benjamin percebeu que esse mundo tomado por uma lei invisível e violenta não atinge apenas ao protagonista. Também as autoridades sofrem os efeitos. Tornam-se corcundas, a cabeça quase tocando no peito, sua aparência deteriorada, como se seus corpos apreendessem o ambiente escuro e mofado de tudo o que, em Kafka, encarna um tribunal ou órgão público.

\section{O ELEMENTO TEOLÓgICO E O ESPAÇO PARA A RESISTÊNCIA}

Por fim, resta tratar do papel político que esse elemento teológico encerra ao direito.

Em sua obra Limiar, aura e rememoração, Jeanne Marie Gagnebin (2014) remonta como Theodor Adorno nutria um grande entusiasmo pela obra de Bertold Brecht e que tal não era o seu sentimento com respeito aos escritos de Kafka. Adorno via, no universo teológico de Kafka, caminhos sem saída e um sentido perdido que induziam o leitor ao conformismo, na medida em que um dos elementos mais óbvios na prosa de Kafka é a total falência de qualquer das tentativas de êxito administradas por seus heróis.

Essa intepretação pouco entusiasmada, como nesse caso é notório, vem da parte de alguém que busca num texto crítico o apontar de um caminho para o agir, uma crítica que trilha ou ao menos permite que outros possam trilham um caminho emancipatório.

Também com o texto de Fitzpatrick ocorreu algo semelhante. Não por acaso, a introdução à edição brasileira, escrita pelo autor em 2007, visa justamente a responder acusações que lhe imputam um tom de conformismo. Afinal de contas, se o direito moderno possui ainda sustentáculos míticos, quais as consequências disso para a práxis cotidiana 
e as violências que ela reproduz? Quer se chame o fundamento último de um sistema jurídico de convenção compartilhada quer se chame de "um fundo de narrativas míticas”, os elementos factuais não permanecem os mesmos? Se, por outro lado, o livro se propõe a denunciar a persistência do mito, voltando-se assim à necessidade de afastá-lo e de alcançar finalmente uma comunidade que tenha transparência acerca de todos os fios condutores de suas práticas sociais, não repetiria o livro o mesmo erro que critica na modernidade? Não buscaria também Fitzpatrick uma leitura que afasta o mito como selvagem e atrasado e alcança finalmente a idade da razão (Fitzpatrick, 2007, p. 19)?

Diferente da resposta dada no prefácio à $2^{\mathrm{a}}$ edição de sua obra, diversos artigos de Fitzpatrick como o citado "Agonism and the limits of law" dão margem a essa leitura, na medida em que não chegam a uma conclusão, mas terminam geralmente em impasses e em narrativas aporéticas que não têm como confluir a nada produtivo. E deve-se ressaltar que Fitzpatrick admira muito em Kafka justamente o modo como seus protagonistas inevitavelmente falham, o modo como aquele sentido que é buscado no começo da obra mostra-se mais e mais invasivo, porém ausente, isto é, irradiando uma proximidade e ao mesmo tempo cada vez mais definitivamente inalcançáveis. O único êxito que o protagonista pode alcançar é a compreensão da inevitabilidade da sua falha. É aqui, entretanto, que algo interessante se esconde.

Agamben percebeu o potencial crítico de Kafka em uma interpretação bastante apropriativa de $O$ processo, quando afirmou que se trata de um processo de calúnia movido por Joseph K. contra si mesmo (Agamben, 2009). Por ter estudado a história das instituições jurídicas romanas, o filósofo italiano lembrou que o falso testemunho era crime gravíssimo no direito romano, punido com a marca $K$. na testa, que significava Kalumniator. Lendo uma série de indícios ao longo do texto, Agamben busca mostrar que o processo só existe dentro da imaginação de K. e que só ganha corpo a partir de atos performados por $\mathrm{K}$.

Essa leitura, como afirmou com precisão Daniel Arruda Nascimento, parece à primeira vista fraca e facilmente contestável por diversas páginas nas quais destoa a realidade inescapável do processo (Nascimento, 2014, p. 145). O potencial crítico da interpretação de Agamben, que no fundo é o que 
importa aqui, só fica claro quando a essa leitura se une outro elemento fundamental. Para Agamben, afirma Nascimento

\begin{abstract}
a autocalúnia faz parte da estratégia de Kafka no seu incessante corpo-a-corpo com a lei. [...] Se a acusação é falsa e se, de outra parte, acusador e acusado coincidem, então é a própria implicação fundamental do homem no direito que é colocada em questão. O único modo de afirmar a própria inocência diante da lei é, neste sentido, acusar-se falsamente (Nascimento, 2014, p. 145)
\end{abstract}

Como se vê, a acusação falsa seria assim a saída para gerar um curto circuito na lei, ou seja, para torná-la acessível em um momento falso, para chamá-la à sua violência inefável no momento em que não lhe caberia.

Seria preciso, agora, reunir esse pensamento com a leitura de Fitzpatrick em que Kafka demonstra o potencial de um fracasso. O fato de o herói estar sempre lutando com algo que está além de suas forças, com aleatoriedades cujo ponto comum de explicação foi rompido, tudo isso só é conformista e puramente surreal se a leitura concluir pela história de uma derrota. Mas essa não é a história de uma derrota.

Com o perdão mais uma vez do recurso à biografia, a escrita foi o modo que o amedrontado Kafka encontrou para vencer o silêncio que lhe foi imposto pelo Pai, pela vida de estrangeiro, pela perda geral de um norte no contexto da guerra do começo do séc. XX.

Como respondeu Fitzpatrick aos críticos, escrever sobre o direito moderno em meio a narrativas aporéticas também não é uma forma de renomear as bases da práxis. Pelo contrário, no caso de Fitzpatrick, trata-se de atacar o colonialismo, a violência simbólica, o machismo e uma série de outros elementos que estão presentes e ao mesmo tempo negados pelos pressupostos do direito moderno. Nesse caso, trata-se de mostrar como é perfeitamente possível a essa estrutura sustentar universalidade e machismo ao mesmo tempo, assim como é plenamente compatível e até complementar pensar em direitos humanos universais e caracterização dos indígenas como selvagens e atrasados.

Em seu livro A potência do pensamento, Agamben (2015) aponta que algo se esconde por trás da aparente derrota total na parábola "Diante da lei”. No fim da parábola, percebendo a morte iminente do camponês, o porteiro se aproxima e, sendo perguntado acerca da razão pela qual até então ninguém tentara entrar por aquela porta, responde de forma 
triunfante que aquela porta fora destinada somente ao camponês, motivo pelo qual agora ele, porteiro, a fecharia e iria embora.

Como dito acima e inclusive ressaltado na leitura de Fitzpatrick, há aqui um importante enigma, na medida em que a entrada na lei é inacessível, porém suas portas estão abertas. De sua abertura vem uma luz que cega até o porteiro. $\mathrm{O}$ camponês passa a vida acreditando na realidade e na tangibilidade dessa luz, não conseguindo jamais alcançá-la.

Será que a abertura das portas ajuda de alguma forma a sustentar a ilusão de sua plena inacessibilidade? Se isso for verdade, o fechamento ulterior à morte do camponês diz algo também acerca do esplendor daquela lei e mesmo da necessidade de haver um porteiro.

Será que Agamben está aqui tentando fazer mágica com migalhas? Será que sua interpretação busca infrutiferamente pontos mínimos de refúgio onde só existe ausência e impotência?

O que se pode responder aqui é que foi nesse fio da navalha que viveu Kafka, o mesmo em que viveram aquelas personagens de "Sobre a questão das leis" e o mesmo, ainda, em que se sustenta e pode se sustentar qualquer teoria que procure um espaço de crítica emancipatória em meio ao labirinto da racionalidade jurídica moderna. O fato é que, sem Kafka, esse elemento mítico dificilmente seria arrancado de seu confortável velamento.

\section{CONCLUSÃ̃o}

O propósito central do presente artigo foi apresentar, a partir da leitura de Kafka realizada por Peter Fitzpatrick, as aporias nas quais se encontra enredada a compreensão moderna do fenômeno jurídico. Ao invés de relevar exatamente o que é o direito por trás de alguma máscara ou discurso, Fitzpatrick mostrou justamente que o que se entende por direito moderno resulta de uma série de elementos contraditórios, que só podem ser unidos e apresentados de forma coerente a partir de uma narrativa mítica.

Tal como a lei que se acredita que exista, mas que apenas os nobres conhecem, ou como as portas abertas, porém intransponíveis da lei, Fitzpatrick se valeu da narrativa literária de Kafka para criticar a lógica de um direito que superou a transcendência e cujo conteúdo é agora plenamente construído e conhecido por autoridades claramente definidas. 
A crítica dos elementos míticos do direito moderno, embora tome a roupagem de um diálogo filosófico, possui papel relevante enquanto resistência crítica, justamente na medida em que permite que se perceba como a lei moderna pode acomodar elementos contraditórios como universalidade e racismo, igualdade e sexismo, liberalismo e censura. Tudo isso é possibilitado uma vez que, não sendo palpável, o direito pode tornarse penetrante e conciliar elementos contraditórios.

Foi exatamente esse elemento que o artigo buscou trazer quando, sob a luz da leitura teológica, tratou de como o processo kafkiano nunca realmente acontece e ao mesmo tempo se encontra em todos os lugares, tal como ocorre também com o discurso teológico, cujo tom é o de algo que escapa à completa compreensão, ao mesmo tempo que preenche tudo.

Como dito acima, o modo como a obra de Kafka propicia a reflexão crítica não é a partir da narrativa do triunfo de um herói, mas do relato de uma derrota, de uma perda, de algo que há muito se tornou compreensível e que parece não oferecer nenhuma saída. O protagonista, geralmente chamado K., falha sempre e sofre todo tipo de arbitrariedade e de impossibilidades. A questão é que, por meio desse não atingimento e desses caminhos sem saída, Kafka mostra as aporias nas quais a modernidade se enredou e encontra, no vão pequeno e quase imperceptível de um lampejo, um espaço para resistência.

\section{REFERÊNCIAS}

AGAMBEN, Giorgio. A potência do pensamento: ensaios e conferências. Trad. de Antônio Guerreiro. Belo Horizonte: Ed. Autêntica, 2015.

BENJAMIN, Walter. Franz Kafka. A propósito do décimo aniversário de sua morte. In: BENJAMIN, Walter. Obras escolhidas. Trad. de Sérgio Paulo Rouanet. São Paulo: Brasiliense, 1987. v. 1.

BROD, Max. Franz Kafka; a biography. Trad. de G. Humphreis Roberts e Richard Winston. New York: Schocken Books, 1978.

BUTLER, Judith. Relatar a si mesmo: crítica da violência ética. Trad. de Rogério Bettoni. Belo Horizonte: Autêntica, 2015.

DELEUZE, Gilles; GUATTARI, Félix. Kafka: por uma literatura menor. Trad. de Cíntia Vieira da Silva. Belo Horizonte: Autêntica, 2014.

FITZPATRICK, Peter. A mitologia na lei moderna. Trad. de Nélio Schneider. São Leopoldo: Unisinos, 2005. 
FITZPATRICK, Peter. Political agonism and the (im)possibility of Law: Kafka's Solution. Teoria e Critica della regolazione sociale, n. 2, p. 97-115, 2015.

GAGNEBIN, Jeanne Marie. Filosofia e literatura. Limiar, v. 3, n. 5, p. O4-14 2016.

GAGNEBIN, Jeanne Marie. Limiar, aura e rememoração. São Paulo: Editora 34, 2014.

KAFKA, Franz. Carta ao pai. Trad. de Modesto Carone. São Paulo: Editora 34, 1997a.

KAFKA, Franz. Na colônia penal. Trad. de Modesto Carone. São Paulo: Companhia das Letras, 1997b.

KAFKA, Franz. Narrativas do espólio. Trad. de Modesto Carone. São Paulo: Companhia das Letras, 2002.

KAFKA, Franz. Das Urteil. Köln: Anaconda, 2008.

KAFKA, Franz. O processo. Trad. de Marcelo Backes. Porto Alegre: L\&PM Pocket, 2012.

KELSEN, Hans. Teoria pura do direito. Trad. de João Batista Machado. 6. ed. São Paulo: Martins Fontes, 1998.

NASCIMENTO, Daniel Arruda. Umbrais de Giorgio Agamben: para onde nos conduz o "homo sacer". São Paulo: LiberArs, 2014.

OST, François. Contar a lei: As fontes do imaginário jurídico. Trad. de Paulo Neves. São Leopoldo: Unisinos, 2004.

PUCHEU, Alberto. Kafka poeta. Rio de Janeiro: Azougue, 2015.

SANTOS, Bruno Barbosa. Leituras de Kafka: escólios sobre a burocracia e o exercício da lei. Cadernos de estética aplicada, n. 21, p. 51-68, 2017. Disponível em: <http://www.revistaviso.com.br/visartigo.asp?sArti=228 $>$. Acesso em: 11 jan. 2018.

WILliams, James. Pós-estruturalismo. Trad. de Caio Liudvik. 2. ed. Petrópolis: Vozes, 2013.

Idioma original: Português

Recebido: 18/02/18

Aceito: 28/06/18 